\title{
The Invention of Science: A New History of the Scientific Revolution. By David Wootton. 2015. Harper Collins, New York. 784 pp.
}

\author{
Eugene N. Anderson ${ }^{1 *}$ \\ ${ }^{1}$ Department of Anthropology, University of California, Riverside, USA. \\ *eugene.anderson@ucr.edu
}

Received May 1, 2016

OPENӘACCESS

Accepted June 8, 2016

\author{
DOI 10.14237/ebl.7.1.2016.716
}

Copyright $@ 2016$ by the author(s) licensee Society of Ethnobiology. This is an open-access article distributed under the terms of the Creative Commons Attribution-NonCommercial 4.0 International Public License (https://creativecommons.org/licenses/by-nc/4.0), which permits non-commercial use, distribution, and reproduction in any medium, provided the original author and source are credited.

For those who are less than convinced by postmodernist claims that the scientific revolution never happened, and not convinced at all by the claims that science is a mere word game, this book is a river-not just an oasis-in the desert. David Wootton robustly defends the old idea that the revolution begun by Tycho Brahe and Galileo and led to victory by Isaac Newton was real and important. His opening sentence (p. 1) reads: "Modern science was invented between 1572, when Tycho Brahe saw a nova, or new star, and 1704, when Newton published his Opticks, which demonstrated that white light is made up of light of all colors..." His final paragraph restates those dates, and adds the specific information: "Science- the research programme, the experimental method, the interlocking of pure science and new technology, the language of defeasible knowledge-was invented between 1572 and 1704" (p. 571). I thought I knew English, but "defeasible" stopped me; the OED informs that it means "Capable of being undone, 'defeated'...." It is here a nod to Karl Popper's famous argument that scientific statements must be capable of accepted disproof, but-perhaps more importantly-it flags the extreme importance of realizing that the ancients, even the near-divine Aristotle, were often wrong, and the moderns had to check their knowledge.

What was new, as Francis Bacon pointed out at the time, was that the authority of the ancients gave way to experimentation, exploration, testing, and research. Wootton points out the enormous importance of Columbus' "discovery"-from a southern European point of view_of the Americas, and the realization that they were a whole new vast realm. This, in fact, made the word "discovery" enter our languages; it was an obscure Portuguese term (descubrimento) that went viral after Columbus. One might add (and I think Wootton should have added) that Europeans were also traveling to Africa and Asia more, and getting acquainted with a vast range of new plants and animals. Of course Aristotle, Galen, and the other ancients had known nothing of these.

Meanwhile, great strides in anatomy, medicine, chemistry, physics, and other areas were being made. Among new words that came later was "fact," originally a term of medieval law, appropriated in the 17 th century for one type of thing science is supposed to find. But science is also supposed to find "natural laws," another new term. Experiment, theory, hypothesis, and, later, probability also added to the language (p. 565 sums up hundreds of pages of history of these concepts). Wootton has been characterized in some once-over-lightly reviews of taking a linguistic stance, but he is really interested in the scientific processes that led to the concepts that then had to have a name. His history is one of progressive "discovery" and "experiment." These required new terms, and that is an important observation, but does not make his book a linguistic study.

Finally, Wootton embarks on a devastating critique of the more extreme forms of relativism and social constructionism. Clearly, science does find out stuff. It lets us do all kinds of things the ancients couldn't do. America is real. Chemistry works and alchemy doesn't. (They were not distinguished until quite late; Newton was still trying alchemy in the 17th century, though Wootton emphasizes that he had to 
be a bit secretive about it, since it was losing ground). Verification and disproof really do happen.

However, Wootton sometimes gets a bit carried away. He ascribes more extreme positions to modern "science studies" scholars than they really hold. Latour, for instance, is less of a relativist that Wootton says (p. 540). Thomas Kuhn was less dogmatic about his model (Kuhn 1962) than Wootton seems to think. But this is minor and debatable. More serious is Wootton's missing some "facts" of his own. Minor, but revealing, is his claim that "Mt. Everest was...just as tall before it was named in 1865 as it was after it was named, but finding and sharing facts about Everest required a naming process...there were no facts about Everest before 1865" (p. 260). Of course Everest was named (Jolmolungma, to be exact) and perfectly well known, mapped, and (up to a fairly substantial altitude) explored, and had been so for millennia. It was well known to Tibetan and Chinese science. Again, arguing for "killer facts" (killing theories, that is), he says: "If I wanted to persuade you of continental drift, for example, I would point you to the classic papers on paleomagnetism and we could then go and make our measurements in the field" ( $p$. 280). Well, there were plenty of killer facts proving continental drift beyond reasonable doubt as early as the 1930s, and the paleomagnetic work was done in the 1960s, but most geologists were not convinced until around 1970 or later. Very slow acceptance was driven by heavy investment in outmoded theories. Nothing could more firmly prove Kuhn's points about "normal science" and occasional "revolutions," or more thoroughly refute the more naïve claims of killer facts.

Indeed, to build a bit on Kuhn, one can say that science requires error to advance. People have to propose wild theories, push the envelope, approximate, and outright guess, just to generate the new ideas that may someday develop into great science. This is why I am less hard than the organization "scientists" are on traditional peoples who explain earthquakes as the shaking of a giant animal underground, and explain sickness as the result of bad air currents. They are as correct as western science was on these issues 200 years ago. The problem comes, as Wootton makes clear, when people refuse to test, refine, and build on these ideas.

This makes us wonder whether Wootton is too quick to dismiss the constructionist and relativist positions. Showing that science does really advance useful knowledge does not prove it is immune to sociocultural pressures. Wootton describes himself as a qualified constructionist, aware that science and scientific knowledge are indeed socially constructed; they are, however, constructed through interaction with external reality (whatever that is-best defined by some anonymous sage as "the stuff that refuses to go away when I stop believing in it"). This is true enough, but does not explain the specific errors, standpoints, biases, and other baggage that are inseparable from the dispassionate pursuit of truth. Society and culture are unavoidably involved with this. Wootton and his constructionist targets agree on one thing that I find impossible to believe: The idea that truth and social construction are mutually exclusive. No, truth almost has to be socially constructed. It takes a village to raise a child and establish a fact.

It follows that scientific truths have a long social history, often one in which they developed from flagrant error, as chemistry did (in part) from alchemy and as theories of contagion by germs built on theories of contagion by bad air ("mal-aria"). This is, of course, quite different from pseudosciencenonsense that was against all evidence from the start and that is propagated by public-relations gimmicks rather than experiment or evidence.

True science is a social construction just as error is, and Wootton seems to me to be quite wrong in denouncing those who see a need to explain both in social and cultural terms. In fact, Wootton's whole book is dedicated to explaining how people got to the truth, and it was a social process.

Still, Wootton is obviously correct about the extreme importance of the scientific revolution and its invention of science as an institution, a calling, and a process. The key difference between the search for truth and a fall into error is exactly what made the scientific revolution a real revolution: a dedication to test all knowledge against experience, experiment, and evidence.

One need only point to a fascinating close comparison case: China. China's pre-1600 scientific knowledge developed at about the same rate as the West's. It was equally stuck with its own ancients; the Chinese classics were as rigidly followed there as Aristotle and Galen were in medieval Europe. Chinese scholars were equally loath to experiment or test-but equally prone to do so anyway, because of insatiable curiosity. China learned a great deal from the West, as the West did from China. All seemed one big happy 
system. Famously, all the three inventions that Francis Bacon thought were basic to the rising science of his time - the compass, gunpowder, and printing - were Chinese inventions, learned late in the West.

Then, in the late 1500s, the West suddenly exploded. In 1572, China was about equal to the West in botany, astronomy (they had recorded a nova in 1054), physics, technology, medicine, everything. By the early 1600s, China was already hopelessly behind in some fields, and by the middle 1600s China was in the dust. One reason was the fall of the Ming Dynasty, which reduced China to bloody chaos and ended peaceful investigations for a long time. Then the following Qing Dynasty was fiercely repressive, sending scholars back to the classics. Meanwhile, the West suddenly leaped, while China kept cranking along at the same old rate. (See the many volumes of Science and Civilisation in China; also Elman 2005, 2006.) Similarly, the Muslim world had a brilliant scientific tradition that anticipated much of Europe's later revolution (see Beckwith 2013; Starr 2013), but it collapsed in the Turkic and Mongol wars of the 1200s. Wootton does not discuss these cases, but he gives us the best explanation to date of why and how the West developed as it did, rapidly surpassing these others.

Evidently, the enemy of truth is not error, but blind devotion to untested or untestable theories, as everyone from Bacon to Popper and Wootton point out. This should sober those anthropologists that take seriously the wilder flights of French postmodernism.

But was the West inventing science in the sense of systematic pursuit of useful knowledge about the external world? Obviously not-China was indeed equal to the West in 1572, in most areas, and well ahead in some (notably nutrition). Even the ancient Greeks (oft derided by Wootton, who finds Aristotle especially wanting) did very well. Wootton does not mention botany; in that area the Greeks, notably Theophrastus and Dioscorides, did brilliant work that remains foundational to the field. Medieval science in Europe and elsewhere made significant strides in medicine and in such fields as falconry; Frederick II Hohenstaufen (1943, Latin original ca. 1250) wrote a book on that subject that is still used as an authoritative text, and he explains in detail the fully scientific methods he used, anticipating much of what Wootton says was new 400 years later.

Indeed, as we ethnobiologists know, every culture and society on earth has science, in that all of them learn a great deal from interacting with the environment, accumulate this as best they can in developing knowledge, and systematize it through all those wondrous taxonomies, rules, cultural models, and other things we study. Some even have terms more or less equivalent to post-1650 "science." Admittedly, it is easier to accumulate and share knowledge if you have writing, and much easier if you have printing (as Wootton emphasizes-following Bacon), but the Chinese and central Asians had printing and it did not enable them to leap forward. Yet many Indigenous nonliterate societies have very extensive knowledge bases learned through experience and non-written teachings. In fact, Europe in the 1500s was not really taking as much advantage of printing as one might think. In science, for the most part, print books merely recorded oral knowledge.

So I prefer to think of science as a human universal, and to use for post-1500 western science my friend Randall Collins" useful term "rapid discovery science" (1998). Using the term "science" for ancient Greek geometry, astronomy, and so on is long established, and if that seems fair-which it does - then every culture has science. What the West did after 1500 was create a self-conscious science that was dedicated to finding out as much as possible, as fast as possible.

Wootton shows that the standard explanations for the rise of rapid discovery science are inadequate, and does not propose a new one. I can only add that science developed along with trade, commerce, and exploration, and also by religious diversity and controversy. It was set back by autocratic regimes whenever and wherever they arose. This cost of autocracy is the usual, and certainly at least partly true, explanation for China's failure. Italy was a leader in science when divided into city-states, and lost the lead when it was centralized. Later, of course, science flourished in some large and centralized societies (like the United States), but not in really authoritarian ones. This is only a partial explanation, though, and we are left wondering.

\section{References Cited}

Beckwith, C. 2013. Warriors of the Cloisters: The Central Asian Origins of Science in the Medieval World. Princeton University Press, Princeton, NJ.

Collins, R. 1998. The Sociology of Philosophies. Harvard

University Press, Cambridge, MA. 


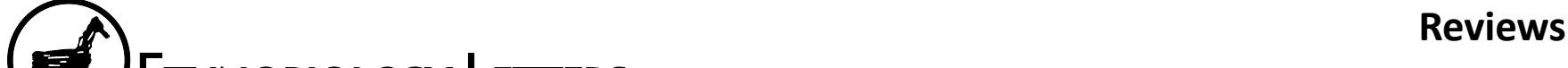 ETHNOBIOLOGY LeTters Perspectives from Gene Anderson's bookshelf}

Elman, B. 2005. On Their Own Terms: Science in Cbina, 1550-1900. Harvard University Press, Cambridge, MA.

Elman, B. 2006. A Cultural History of Modern Science in Cbina. Harvard University Press, Cambridge, MA.

Hohenstaufen, F. II. 1943. The Art of Falconry.

Translated and edited by C. A. Wood and F. M.

Fyfe. Stanford University Press, Stanford, CA.
Kuhn, T. 1962. The Structure of Scientific Revolutions. University of Chicago Press, Chicago, IL.

Starr, S. F. 2013. Lost Enlightenment: Central Asia's Golden Age from the Arab Conquest to Tamerlane. Princeton University Press, Princeton, NJ. 